\title{
Perancangan Sistem Informasi Pendaftaran Siswa Baru di SMK YASTRIF 1 Parung Panjang Berbasis Web
}

\author{
Ismi $^{1}$, Ratna Willis ${ }^{2}$, Siti Soliah ${ }^{3}$, Iyus Tiawati ${ }^{4}$, Yulianti ${ }^{5}$ \\ Teknik Informatika, Universitas Pamulang, Tangerang Selatan, Indonesia \\ e-mail: ismisyg24@gmail.com, ratnawillis4@gmail.com, sitisoliah.id@gmail.com, \\ tiayus042@gmail.com,yulianti@unpam.ac.id
}

Submitted Date: October $02^{\text {nd }}, 2020$

Revised Date: November 02 $2^{\text {nd }}, 2020$
Reviewed Date: October $08^{\text {th }}, 2020$

Accepted Date: November $02^{\text {nd }}, 2020$

\begin{abstract}
In this millennial era, the development of technology has really sped up the difference compared to the previous era. Every day, even at the clock, there are always new developments in technology. Invarious fields, everything wants to be practical and fast, all of that cannot be separated from new discoveries from technology plus millennials who want everything instant and fast. People nowadays are almost all technology literate, one of which is the internet. Just by sitting pretty and connected to the internet, everything can be done without having to leave the house. Parents and school children don't have to bother queuing just to register for school, just open the internet, everything can be done at any time. This study aims to make it easier for new students who are millennials by building online media, namely websites using the HTML programming language, MySQL database. Prospective students only need to be connected to the internet and can register for schools and be more efficient.
\end{abstract}

Keywords: Information Systems; Website; Internet; New Student Registration; Millennial

\begin{abstract}
Abstrak
Di era milenial ini perkembangan teknologi benar-benar melesat jauh perbedaannnya dibandingkan era sebelumnya. Setiap hari bahkan jam selalu ada perkembangan baru dalam teknologi. Dalam berbagai bidang semuanya ingin serba praktis dan cepat, semua itu tidak bisa terlepas dari penemuan-penemuan baru dari teknologi ditambah kaum milenial yang segalanya ingin instan dan cepat. Masyarakat sekarang hampir semuanya melek teknologi salah satunya internet. Hanya dengan duduk manis dan terkoneksi internet semuanya bisa dilakukan tanpa harus keluar rumah. Para orang tua dan anak sekolah tidak perlu repot antri hanya untuk daftar sekolah, cukup buka internet semuanya bisa dilakukan kapanpun. Kajian ini bertujuan untuk mempermudah peserta didik baru yang merupakan kaum milenial dengan membangun media online yaitu website menggunakan bahasa pemrograman HTML, basis data MySQL. Calon siswa cukup terhubung ke internet saja sudah bisa daftar sekolah dan lebih efisien.
\end{abstract}

Kata kunci: Sistem Informasi; Website; Internet; Pendaftaran Siswa Baru; Milenial

\section{Pendahuluan}

Pada saat ini teknologi informasi semakin berkembang pesat dalam membantu masyarakat dalam memecahkan suatu masalah, maupun dalam meningkatkan efektivitas dan efisiensi dalam aktivitas manusia, salah satunya dalam bidang pendidikan. Pemanfaatan teknologi informasi sangat penting, karena ditujukan untuk membantu pekerjaan dengan menyediakan informasi dan melakukan berbagai tugas yang berhubungan dengan pengolahan informasi (Hanum \& Saifudin,
2019). Kebutuhan terhadap teknologi dan informasi sangat tinggi untuk membantu berbagai jenis bidang pekerjaan manusia (Taufiq, Magfiroh, Yusup, \& Yulianti, 2020). Salah satu tujuan teknologi informasi sendiri adalah untuk mengolah (processing) data masukkan yang diterima untuk menjadi informasi.

Pengolahan data, ini juga sangat membantu dalam bidang pendidikan. Selain untuk mempermudah staf tata usaha dalam mengolah data siswa dan guru, perkembangan teknologi informasi 
juga bisa menjadi sarana bagi guru dan siswa untuk berinteraksi secara online atau tanpa tatap muka secara langsung, dan dengan penerapan perkembangan teknologi informasi dalam pendidikan juga dapat membantu para calon-calon siswa untuk mencari informasi tentang sekolahsekolah favorit mereka sebelum mendaftar.

SMK Yastrif 1 Parung Panjang merupakan sekolah swasta yang berada di jalan Raya Moh Toha, Parungpanjang, Bogor. Dalam proses penerimaan siswa baru, SMK Yastrif 1 Parung Panjang masih melakukan proses pendaftaran menggunakan metode tulis tangan dalam mengisi formulir pendaftaran dan dari segi panitia sendiri dalam pendataan calon peserta didik baru yang mendaftar. Calon peserta didik sulit mendapatkan informasi-informasi tentang lingkungan sekolah, prestasi sekolah dan proses pendaftaran. Dan apabila ingin mendapatkan formulir pendaftaran, para calon peserta didik diharuskan datang ke sekolah, sehingga hal itu cenderung lambat dan memakan waktu. Pihak sekolah juga masih menggunakan arsip dalam bentuk fisik, di mana hal itu sangat rentan mengalami dalam kerusakan atau bahkan hilang. Sistem yang masih konvensional dapat mengakibatkan administrasi penerimaan siswa baru cenderung lambat, karena datanya belum terintegrasi dan terkelola dengan baik (Witanto \& Solihin, 2016). Maka dari itu SMK Yastrif 1 Parung Panjang membutuhkan konsep dan mekanisme penerimaan peserta didik baru yang memanfaatkan teknologi informasi.

Berdasarkan masalah di atas maka diusulkan untuk membuat aplikasi untuk penerimaan peserta didik baru yang dirancang menggunakan bahasa pemrograman PHP dan MySQL. Aplikasi yang akan dibuat mencakup halaman profile sekolah, profile pengajar, prestasi sekolah, dan data siswa yang mendaftar akan tersimpan rapih di MySQL. Mempertimbangkan kondisi saat ini yang sedang adanya wabah virus covid-19, maka diusulkan untuk membuat website pendaftaran siswa baru. Aplikasi website yang dapat diakses melalui jaringan internet dapat memudahkan calon siswa untuk mendaftar tanpa harus datang ke sekolah (Amin, 2017). Calon siswa baru tidak perlu datang ke sekolah untuk mengambil formulir sehingga dapat meminimalisir keramaian dan mencegah penularan virus tersebut, serta dapat memudahkan panitia dan calon siswa dalam proses pendaftaran, cara terbaiknya dengan pendaftaran secara online.

Dengan demikian dilihat dari masalah yang dijelaskan di atas dengan membuat website pendaftaran siswa baru agar dapat memudahkan panitia dalam proses pendaftaran maupun penyimpanan data-data calon peserta didik baru, agar lebih mudah dalam melakukan proses pendaftaran dan lebih cepat untuk mendapatkan informasi-informasi tentang sekolah SMK YASTRIF 1 Parung Panjang.

\section{Metodologi}

Secara umum, sistem dapat diartikan sebagai kumpulan dari elemen-elemen yang berinteraksi untuk mencapai tujuan tertentu sebagai satu kesatuan (Anam, 2018). Dari sumber lain juga didefinisikan, sistem informasi adalah kumpulan dari sub-sub sistem yang saling terintegrasi dan berkolaborasi untuk menyelesaikan masalah tertentu dengan cara mengolah data sehingga memiliki nilai tambah dan bermanfaat bagi pengguna (Taufiq, 2018). Sehingga pada penelitian ini akan dikembangkan sistem pendaftaran siswa baru dengan tujuan untuk mendokumentasikan dan mengolah data-data pendaftaran calon siswa baru.

Penelitian tentang pendaftaran siswa baru di SMK YASTRIF 1 Parung Panjang mengikuti Software Development Life Cycle (SLDC) model waterfall. Adapun model waterfall, yaitu:

1) Tahap perencanaan (planning)

Pada tahap ini yaitu bagaimana kebutuhan dari pengguna mudah dimengerti sehingga pengguna dapat menggunakan website pendaftaran tersebut dengan baik dan benar.

2) Tahap analisis

Proses analisis bertujuan untuk mengetahui kendala apa saja yang terjadi pada saat pengguna memakai website tersebut.

3) Tahap perancangan

Pada tahap ini di mana penulis mampu mencari solusi kendala yang terjadi pada pengguna.

4) Tahap implementasi

Pada tahap ini hasil yang hampir final dari sistem website pendaftaran siswa baru tersebut, seperti membuat kode menggunakan bahasa PHP, database MySQL, dan juga desain sudah berjalan tanpa adanya kekurangan atau cacat. Sehingga pengguna sudah dapat memakai website dengan aman.

5) Tahap pengujian

Pengujian perangkat lunak merupakan tahap yang harus dilalui untuk menjamin kualitas sistem/aplikasi yang dikembangkan (Pratala, Asyer, Prayudi, \& Saifudin, 2020). Pengujian merupakan suatu rangkaian aktivitas yang terencana dan sistematis untuk 
menguji atau mengevaluasi kebenaran fungsi aplikasi berdasarkan desain kasus uji (test case) yang spesifik (Yulistina, Nurmala, Supriawan, Juni, \& Saifudin, 2020). Pengujian perangkat lunak memiliki fungsi yang penting pada pengembangannya untuk menemukan kesalahan (cacat) yang disebabkan oleh perbedaan antara hasil yang diharapkan dengan hasil sebenarnya (Pratama, Ristianto, Prayogo, Nasrullah, \& Saifudin, 2020). Tujuan dari penggujian adalah mengurangi risiko kesalahan dalam sistem website tersebut dan benar-benar dapat berjalan dengan sebaik mungkin

6) Tahap pemeliharaan

Tahap pemeliharaan yaitu tahap mencari kesalahan yang terjadi di saat pengguna mengalami error. Sehingga jika diperlukan akan dilakukan perbaikan dibagian error tersebut secara berkala.

Jika dalam perjalanan pengembangan sistem terjadi kesalahan, kerusakan, ataupun cacat. Maka, akan kembali dilakukan pengulangan dari tahap yang menyebabkan kesalahan, kerusakan, ataupun cacat tersebut. Pengujian merupakan suatu proses pelaksanaan program yang bertujuan menemukan kesalahan dan memperbaikinya sehingga sistem dikatakan layak untuk digunakan (Nurudin, Jayanti, Saputro, Saputra, \& Yulianti, 2019). Sebagai contoh, ketika sedang dilakukan pembangunan sebuah sistem lalu dalam tahap pengujian sistem terjadi kesalahan sistem atau error, maka akan dilakukan pengecekan kembali pada tahap-tahap sebelumnya. Dari kesalahan atau error tadi dilakukan analisis, apakah terjadi error karena dari tahap pertama yaitu analisis atau dari tahap lainnya.

\subsection{Aplikasi Diagram Infrastuktur}

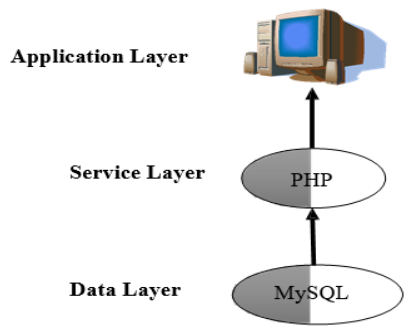

Gambar 1 Diagram Infrastruktur Aplikasi

Di dalam pembuatan aplikasi, penulis menggunakan bahasa pemrograman yaitu PHP, lalu untuk menyimpan data-data menggunakan MySQL sebagai web server. Saat para pendaftar mengakses aplikasi lewat website maka akan memuat halaman website dan juga pendaftar bisa melihat tampilan website seperti halaman profile sekolah, kegiatan sekolah, visi-misi sekolah, dan siswa dapat mendaftar dan akan tersimpan di database.

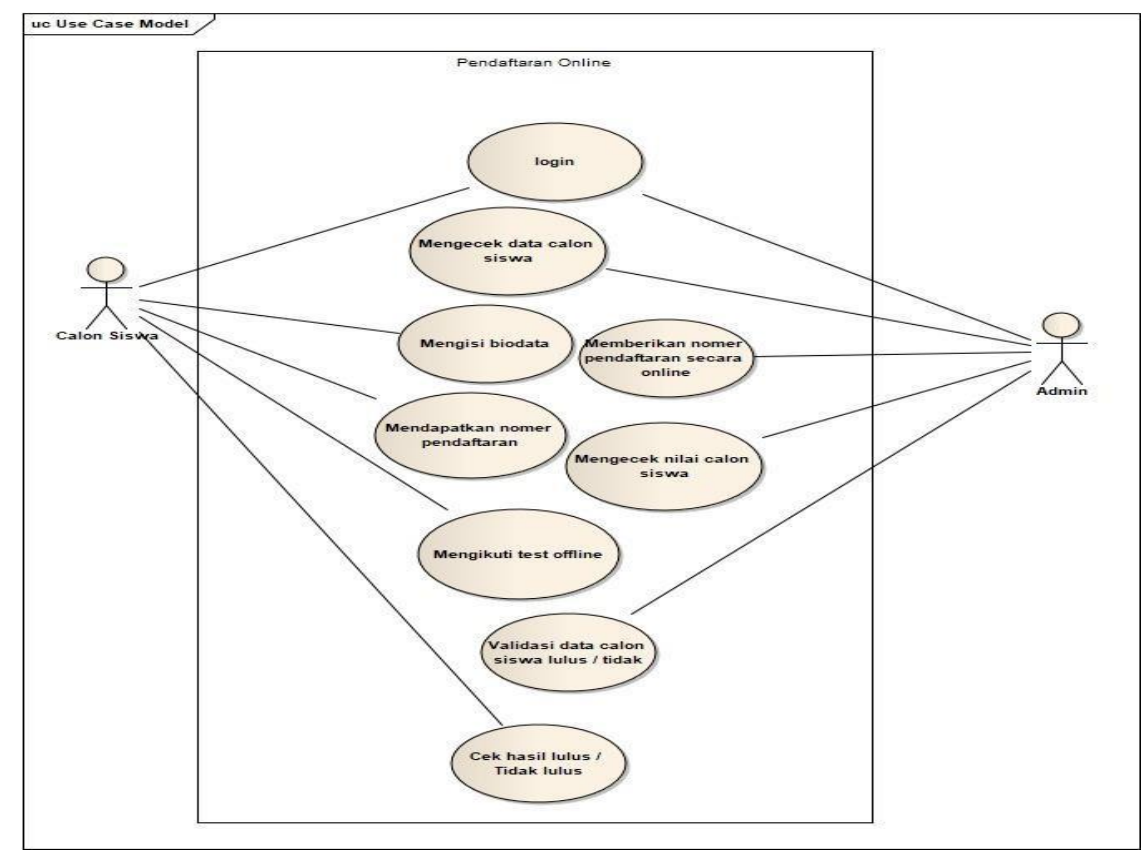

Gambar 2 Tampilan Use Case Diagram 


\subsection{Use Case Diagram}

Pada Gambar 2, dapat dilihat bahwa terdapat 2 aktor pada use case diagram aplikasi yakni calon siswa dan admin. Calon siswa melakukan pendaftaran pada web penerimaan siswa baru, mendapatkan nomor pendaftaran, dan melakukan tes wawancara dan tes, kemudian melihat hasil tes dinyatakan lulus atau tidak. Admin melakukan login, mendata calon siswa yang telah melakukan pendaftaran, dan melakukan pengeditan infomasi dan lain-lain.

\section{Hasil dan Pembahasan}

SMK YASTRIF 1 Parung Panjang merupakan sekolah swasta yang berada di jalan Raya Moh Toha, Parungpanjang, Bogor. Proses penerimaan calon siswa/siswi masih dilakukan secara konvensional yaitu proses pendaftaran masih menggunakan tulis tangan dalam mengisi formulir pendaftaran dan dari segi panitia sendiri dalam pencatatan calon peseta didik yang mendaftar. Calon peseta didik yang ingin melakukan pendaftaran harus datang ke sekolah dan mengambil formulir kemudian mengisinya dan setelah itu menyerahkannya pada staf beserta kelengkapan dokumen- dokumen yang dibutuhkan untuk diproses.

Adapun penerapan program aplikasi yang sudah dirancang dapat dilihat sebagai berikut:

a. Menu Pendaftaran

Beranda yang digunakan untuk mendaftarkan diri para calon siswa. Fungsinya untuk menuliskan identitas diri dan mendaftarkan diri, di mana para calon siswa baru wajib mengisi sesuai biodata masing masing, karena form ini sangat wajib diisi agar bisa masuk ke dalam form login.

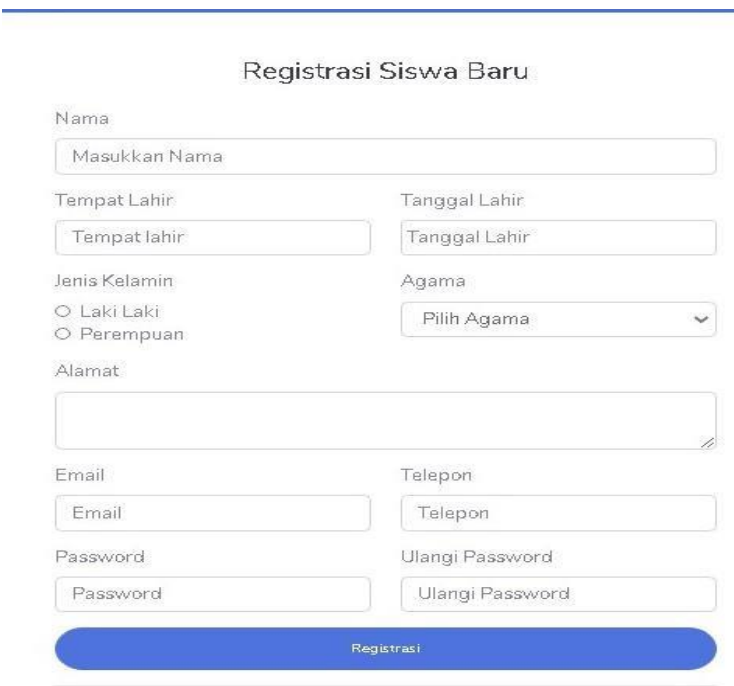

Gambar 2. Tampilan Menu Pendaftaran

b. Menu Calon Siswa

Berfungsi untuk mengedit biodata yang kemungkinan salah saat mengisi form pendaftaran. Di dalam dashboard siswa juga para calon siswa dapat mengirim foto sesuai ketentuan yang berlaku, mengunggah nilai ujian nasional, ujian sekolah dan juga nilai ujian akhir semester.

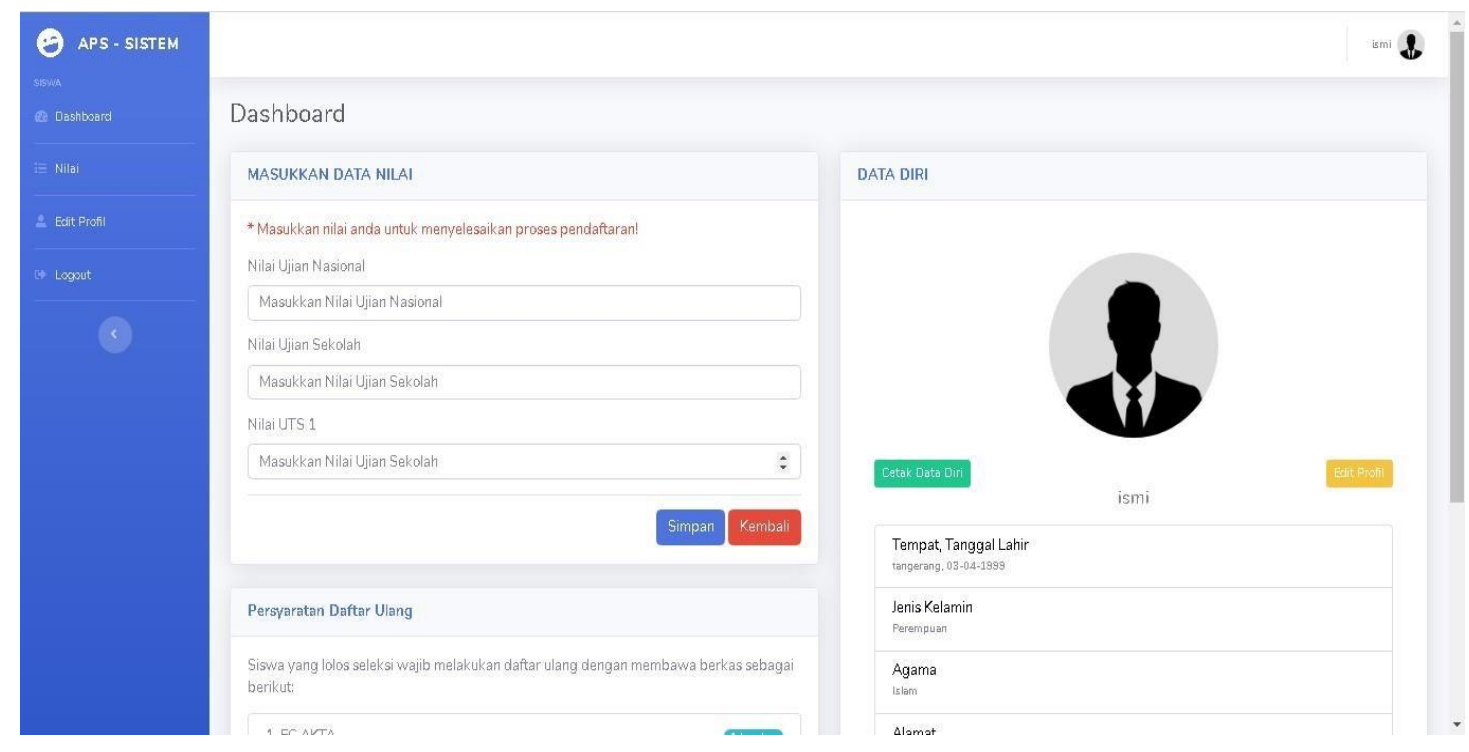

Gambar 3. Tampilan Menu Calon Siswa 
c. Menu Admin

Berfungsi untuk mengecek data para calon siswa sudah sesuai kreteria atau belum, melihat berapa jumlah yang mendaftar, melihat jumlah yang lolos, menentukan lolos atau tidaknya calon siswa dan mencetak laporan data yang mendaftar dan laporan berapa yang lolos seleksi.

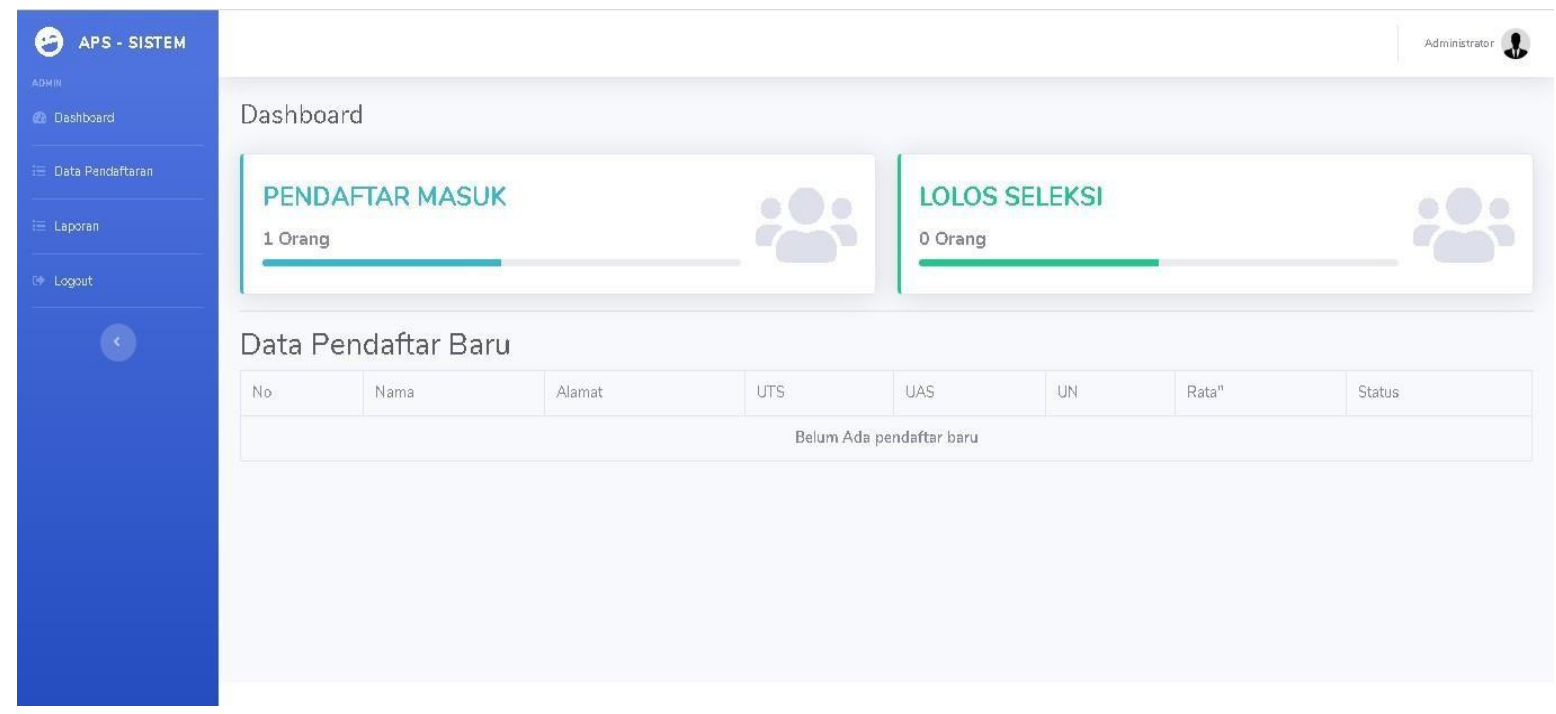

Gambar 4. Tampilan Menu Admin

\section{Kesimpulan} bahwa:

Pada penjelasan di atas dapat disimpulkan

1) Rekayasa perangkat lunak yang dibuat dapat membantu calon siswa dalam proses pendaftaran sekolah.

2) Pengarsipan dokumen dapat terkendali dengan adanya sistem informasi yang diterapkan.

3) Sistem Informasi Akademik Berbasis WEB ini mencakup informasi-informasi SMK Yastrif 1 Parung Panjang yang berupa, profil sekolah, data guru dan siswa, serta informasi dan form pendaftaran siswa baru.

\section{Saran}

Website ini masih memerlukan pengembangan sistem dan pemeliharaan untuk mengetahui kekurangan yang mungkin ada pada saat proses pembuatannya agar website ini lebih baik lagi ke depannya. Pada website sistem informasi sekolah masih perlu dikembangkan untuk desain tampilan dan menambahkan fasilitas agar dapat dijangkau dengan mudah oleh pengguna.

Meski proses pendaftaran sudah memudahkan dengan adanya sistem informasi akademik berbasis web, pengetahuan dasar tentang teknologi merupakan hal penting yang perlu dimiliki agar dapat mengakses web. Maka penulis menyadari bahwa masih diperlukan bimbingan bagi para orang tua murid dan calon siswa dalam proses pendaftaran siswa baru dengan sistem informasi berbasis web ini.

\section{Referensi}

Amin, R. (2017). Rancang Bangun Sistem Informasi Penerimaan Siswa Baru pada SMK Budhi Warman 1 Jakarta. JITK (Jurnal Ilmu Pengetahuan Dan Teknologi Komputer), 2(2), 113-121. Retrieved from https://ejournal.nusamandiri.ac.id/index.php/jit $\mathrm{k} /$ article/view/391

Anam, K. (2018). Analisa dan Perancangan Sistem Informasi Akademik Berbasis Web pada MI Al-Mursyidiyyah Al-'Asyirotussyafi'iyyah. Jurnal Teknik Informatika, 11(2), 207-217. doi:10.15408/jti.v11i2.8867

Hanum, W. S., \& Saifudin, A. (2019). Rancang Bangun Aplikasi Panduan Pariwisata di Kabupaten Banyuwangi Mobile Berbasis Android. Jurnal Teknologi Sistem Informasi dan Aplikasi, 2(2), 59-65. doi:10.32493/jtsi.v2i2.2798

Nurudin, M., Jayanti, W., Saputro, R. D., Saputra, M. P., \& Yulianti, Y. (2019). Pengujian Black Box pada Aplikasi Penjualan Berbasis Web Menggunakan Teknik Boundary Value Analysis. Jurnal Informatika Universitas Pamulang, 4(4), 143-148.

Pratala, C. T., Asyer, E. M., Prayudi, I., \& Saifudin, A. (2020). Pengujian White Box pada Aplikasi Cash Flow Berbasis Android Menggunakan 
Teknik Basis Path. Jurnal Informatika Universitas Pamulang, 5(2), 111-119. doi:informatika.v5i2.4713

Pratama, B. P., Ristianto, I. B., Prayogo, I. A., Nasrullah, \& Saifudin, A. (2020). Pengujian Perangkat Lunak Sistem Informasi Penilaian Mahasiswa dengan Teknik Boundary Value Analysis Menggunakan Metode Black Box Testing. Journal of Artificial Intelligence And Innovative Applications, 32-36.

Taufiq, R. (2018). Pengantar Sistem Informasi. Jakarta: Mitra Wacana Media.

Taufiq, R., Magfiroh, D. A., Yusup, D., \& Yulianti, Y. (2020). Analisis dan Desain Sistem Informasi Pembayaran Sumbangan Pembinaan Pendidikan (SPP) di Di SMK Avicena Rajeg. Jurnal Teknologi Sistem Informasi dan Aplikasi, $\quad 3(1), \quad$ 15-21. doi:10.32493/jtsi.v3i1.4308

Witanto, R., \& Solihin, H. H. (2016). Perancangan Sistem Informasi Penerimaan Siswa Baru Berbasis Web (Studi Kasus : Smp Plus Babussalam Bandung). INFOTRONIK: Jurnal Teknologi Informasi dan Elektronik, 1(1), 5463. doi:10.32897/infotronik.2016.1.1.9

Yulistina, S. R., Nurmala, T., Supriawan, R. M., Juni, S. H., \& Saifudin, A. (2020). Penerapan Teknik Boundary Value Analysis untuk Pengujian Aplikasi Penjualan Menggunakan Metode Black Box Testing. Jurnal Informatika Universitas Pamulang, 5(2), 129-135. doi:10.32493/informatika.v5i2.5366 